\title{
Discovery and molecular characterisation of the first ambidensovirus in honey bees
}

\author{
Sabina OTT RUTAR ${ }^{1}$, Dušan KORDIŠ ${ }^{1,2}$
}

Discovery and molecular characterisation of the first ambidensovirus in honey bees

Abstract: Honey bees play a critical role in global food production as pollinators of numerous crops. Several stressors cause declines in populations of managed and wild bee species, such as habitat degradation, pesticide exposure and pathogens. Viruses act as key stressors and can infect a wide range of species. The majority of honey bee-infecting viruses are RNA viruses of the Picornavirales order. Although some ssDNA viruses are common in insects, such as densoviruses, they have not yet been found in honey bees. Densoviruses were however found in bumblebees and ants. Here, we show that densoviruses are indeed present in the transcriptome of the eastern honey bee (Apis cerana) from southern China. On the basis of nonstructural and structural transcripts, we inferred the genome structure of the Apis densovirus. Phylogenetic analysis has shown that this novel Apis densovirus belongs to the Scindoambidensovirus genus in the Densovirinae subfamily. Apis densovirus possesses ambisense genome organisation and encodes three non-structural proteins and a split VP (capsid) protein. The availability of a nearly complete Apis densovirus genome may enable the analysis of its potential pathogenic impact on honey bees. Our findings can thus guide further research into the densoviruses in honey bees and bumblebees.

Key words: honey bees; densovirus; genome organisation; molecular characterisation

\section{INTRODUCTION}

Honey bees (Apis mellifera) play a critical role in global food production as pollinators of numerous crops (Klein et al., 2007; Fürst et al., 2014). Several stressors cause declining populations of managed and wild bee
Received Avgust 13, 2020; accepted December 13, 2020. Delo je prispelo 13. avgusta 2020, sprejeto 13. decembra 2020

Odkritje in molekularna karakterizacija prvega ambidensovirusa pri čebelah

Izvleček: Čebele igrajo ključno vlogo v svetovni proizvodnji hrane kot opraševalci številnih poljščin. Številni stresorji povzročajo upad populacij gojenih in divjih vrst čebel, kot so degradacija habitata, izpostavljenost pesticidom in patogeni. Virusi delujejo kot glavni stresorji in lahko okužijo številne vrste. Večina virusov, ki okužijo čebele, so RNA virusi iz reda Picornavirales. Čeprav so nekateri ssDNA virusi pogosti pri žuželkah, na primer densovirusi, jih pri čebelah doslej še niso našli. Densovirusi pa so bili najdeni pri čmrljih in mravljah. Pokazali smo, da so densovirusi prisotni v transkriptomu azijskih čebel (Apis cerana) z južne Kitajske. Na osnovi nestrukturnih in strukturnih transkriptov smo ugotovili genomsko strukturo Apis densovirusa. Filogenetska analiza je pokazala, da novi Apis densovirus spada v rod Scindoambidensovirus v poddružini Densovirinae. Apis densovirus ima ambisense organizacijo genoma in kodira tri nestrukturne proteine in razcepljeni VP (kapsidni) protein. Dostopnost skoraj celotnega genoma Apis densovirusa bo omogočila analizo njihovega potencialno patogenega vpliva na čebele. Naše ugotovitve lahko privedejo do nadaljnjih raziskav densovirusov pri čebelah in čmrljih.

Ključne besede: čebele; densovirus; organizacija genoma; molekulska karakterizacija

species such as habitat degradation, pesticide exposure and pathogens (Goulson et al., 2015; Potts et al., 2010; Evans and Schwarz, 2011; McMenamin et al., 2016; McMenamin and Genersch, 2015). Viruses act as key stressors and can infect a wide range of species (Grozinger and Flenniken, 2019). Overt viral infections can result in a

1 Josef Stefan Institute, Department of Molecular and Biomedical Sciences, Ljubljana, Slovenia

2 Corresponding author, e-mail: dusan.kordis@ijs.si 
wide range of symptoms, including wing deformities, discoloration, hair loss, bloated abdomens, trembling, paralysis, and mortality (Chen and Siede, 2007). Honey bee populations have become increasingly susceptible to colony losses due to pathogenic viruses spread by parasitic Varroa mites (Martin et al., 2012).

The majority of honey bee-infecting viruses are RNA viruses of the Picornavirales order (Chen and Siede, 2007; Levitt et al., 2013; Brutscher et al., 2016; McMenamin and Flenniken, 2018; Beaurepaire et al., 2020). Common bee viruses include: the Dicistroviruses (Israeli acute paralysis virus (IAPV), Kashmir bee virus (KBV), Acute bee paralysis virus (ABPV), and Black queen cell virus (BQCV)); the Iflaviruses (Deformed wing virus (DWV), Kakugo virus, Varroa destructor virus-1/DWV-B, Sacbrood virus (SBV), and Slow bee paralysis virus (SBPV)); and taxonomically unclassified viruses (Chronic bee paralysis virus (CBPV) and the Lake Sinai viruses (LSVs)) (reviewed in Chen and Siede, 2007 and Brutscher et al., 2016). Recently identified positive sense single-stranded RNA viruses (+ssRNA) viruses include Bee macula-like virus (BeeMLV) in the Tymoviridae family (Galbraith et al., 2018), Apis mellifera flavivirus and Apis mellifera nora virus 1 (Remnant et al., 2017). Apis mellifera rhabdovirus and bunyavirus were recently described (Remnant et al., 2017) and represent first bee-infecting negative sense single-stranded RNA viruses (-ssRNA).

Honey bees are infected by a small number of DNA viruses (Chen and Siede, 2007). Among double-stranded DNA viruses two honey bee-infecting viruses have been found. The Apis mellifera filamentous virus (AmFV) is from the Baculoviridae family and has been sequenced and characterized (Gauthier et al., 2015; Hartmann et al., 2015). The Apis cerana iridovirus from the Iridoviridae family has not yet been sequenced (Bailey et al., 1976; Bromenshenk et al., 2010; Tokarz et al., 2011). Very recently, a number of single-stranded DNA viruses (ssDNA) associated with Apis mellifera have been reported, belonging to circoviruses (Circoviridae) (Galbraith et al., 2018), genomoviruses (Genomoviridae) (Kraberger et al., 2019), CRESS DNA viruses (Cressdnaviricota) (Kraberger et al., 2019) and microviruses (Microviridae) that infect the honey bee bacterial community (Kraberger et al., 2019).

Although some ssDNA viruses are common in insects, such as densoviruses (Parvoviridae) (Cotmore et al., 2014; Pénzes et al., 2020), they have not yet been found in honey bees. Densoviruses were however found in bumblebees and ants (Schoonvaere et al., 2018; Valles et al., 2013). Here, we show that densoviruses are indeed present in the Apis cerana transcriptome from southern China. Genome organisation and phylogenetic analysis have shown that this novel Apis densovirus belongs to the Scindoambidensovirus genus in the Densovirinae subfam- ily. It is interesting that the Bombus and Apis densoviruses are not very similar and belong to different densoviral genera. Although the Bombus densovirus is also present endogenised in the Bombus impatiens genome, this was not the case for the Apis densovirus. The availability of a nearly complete Apis densovirus genome may enable the analysis of its potential pathogenic impact on honey bees. Our findings can thus guide further research into the densoviruses in honey bees.

\section{MATERIALS AND METHODS}

\subsection{DISCOVERY OF THE APIS AMBIDENSOVIRUS IN PUBLIC TRANSCRIPTOMIC DATABASES}

Sequence database searches were finished in July 2020. The protein queries were diverse densoviral NS1 and VP sequences. The database analysed was the Transcriptome Shotgun Assembly (TSA) at the National Center for Biotechnology Information (www.ncbi.nlm.nih. gov). Comparisons were made using the TBLASTN program (Gertz et al., 2006), with the E-value cut-off set to $10^{-5}$ and default settings for other parameters. TBLASTN searching was restricted to different taxa (Protostomia, Hymenoptera, Apoidea and Apis). Apis cerana transcriptome (erroneously named Apis mellifera carnica) contains 52.177 contigs. Apis ambidensovirus sequences were compared to reference protein sequences of all parvoviruses. DNA sequences of the Apis ambidensovirus were translated with the Translate program (web.expasy.org/ translate/).

\subsection{ANALYSIS OF ENDOGENOUS VIRUS ELE- MENTS}

Endogenous copies of densoviruses were detected using the TBLASTN algorithm against hymenopteran genomes available in the Whole Genome Shotgun Database (WGS) and Sequence Read Archive (SRA) at the NCBI, using densoviral protein sequences as queries. The queries involved NS1, NS2, NS3 and VP protein sequences. Comparisons were made using the TBLASTN program (Gertz et al., 2006), with the E-value cut-off set to $10^{-5}$ and default settings for other parameters.

\subsection{PREDICTION OF PROTEIN DOMAINS}

In order to recognize potential protein domains in the protein sequences analysed, we used NCBI CDD database (www.ncbi.nlm.nih.gov/Structure/cdd/wrpsb.cgi), 
by applying a cut-off E-value of 0.01. All Apis and Bombus densovirus proteins were compared against SMART (smart.embl-heidelberg.de), InterPro (www.ebi.ac.uk/ interpro/) and Pfam (pfam.xfam.org) protein domain databases at default parameters.

\subsection{PHYLOGENETIC ANALYSIS}

To infer the phylogenetic relationships among densoviruses, we used their NS1 protein sequences. Key representatives of the densoviral lineages were included in the phylogenetic analysis. 24 protein sequences of the NS1 were aligned using MAFFT (Katoh and Standley, 2013). Phylogenetic trees were reconstructed using the maximum likelihood (ML) method. For phylogenetic reconstruction, we used IQ-TREE with the in-built automated test to choose the best substitution model for each tree (Trifinopoulos et al., 2016). Branch support was computed for all trees using 100 replicates of parametric bootstrap, and 1000 replicates of the approximate likelihood ratio test and ultrafast bootstrap. The iTOL online tool (http://itol.embl.de/) was used for phylogenetic tree annotation (Letunic and Bork, 2016).

\section{RESULTS AND DISCUSSION}

\subsection{DISCOVERY OF THE ACTIVELY TRANSCRIB- ING DENSOVIRUS IN THE HONEY BEE TRAN- SCRIPTOME}

Densoviruses are infecting diverse insect lineages (Cotmore et al., 2014; Penzes et al., 2020). Previous stud- ies have found numerous endogenised densoviruses in insect genomes (Liu et al., 2011; Francois et al., 2016). Metatranscriptomic analyses of major invertebrate lineages have enabled the discovery of a very large number of novel RNA viruses (Shi et al., 2016). Recently, the metatranscriptomic analysis of diverse invertebrates has enabled the discovery of novel invertebrate DNA viruses (Porter et al., 2019). This methodology can identify actively transcribing DNA viruses in metatranscriptomic libraries. Here, we used this approach to find novel densoviruses in invertebrate transcriptomes at NCBI TSA database. We used both NS1 and VP proteins of diverse densoviruses as queries. A large number of novel densoviruses can be found in invertebrate transcriptomes; some are partial transcripts, while others represent separate NS and VP transcripts or nearly whole genomes. To our surprise, we found the first honey bee densovirus transcripts, with the size range between 1.9 and $2.6 \mathrm{~Kb}$. These transcripts correspond either to the non-structural part of the densovirus genome (encoding NS proteins) or the structural part of the genome (encoding VP proteins). In the transcriptome of the eastern honey bee from China we found 8 VP transcripts (encoding a capsid protein) and 4 NS transcripts (Table 1). The size of the complete Apis densovirus VP protein is 760 amino acids, while the sizes of the NS3, NS2 and NS1 proteins are 177, 298 and at least 546 amino acids, respectively. Among NS transcripts only one encodes the complete set of NS3, NS2 and NS1 proteins (GALO01034698, 2215 bp long). NS1 protein is nearly complete, missing is only the C-terminal part (from 2 to 20 amino acids), depending on the most similar sequences that are quite divergent.

The most similar sequence to the NS1 protein of Apis densovirus is the ant Solenopsis invicta NS1; they are $49 \%$

Table 1: Apis densovirus transcripts

\begin{tabular}{|c|c|c|c|}
\hline Transcript & NCBI accession number & Size of the transcript (in bp) & Presence of the intron \\
\hline \multirow[t]{8}{*}{ VP transcripts } & GALO01020880 & 2454 & no \\
\hline & GALO01020879 & 2571 & yes \\
\hline & GALO01020878 & 2502 & yes \\
\hline & GALO01020884 & 2372 & no \\
\hline & GALO01020881 & 2489 & yes \\
\hline & GALO01020883 & 2420 & yes \\
\hline & GALO01020882 & 2425 & no \\
\hline & GALO01020885 & 2343 & no \\
\hline \multirow[t]{4}{*}{ NS transcripts } & GALO01034701 & 1921 & no \\
\hline & GALO01034700 & 1998 & no \\
\hline & GALO01034699 & 2138 & no \\
\hline & GALO01034698 & 2215 & no \\
\hline
\end{tabular}




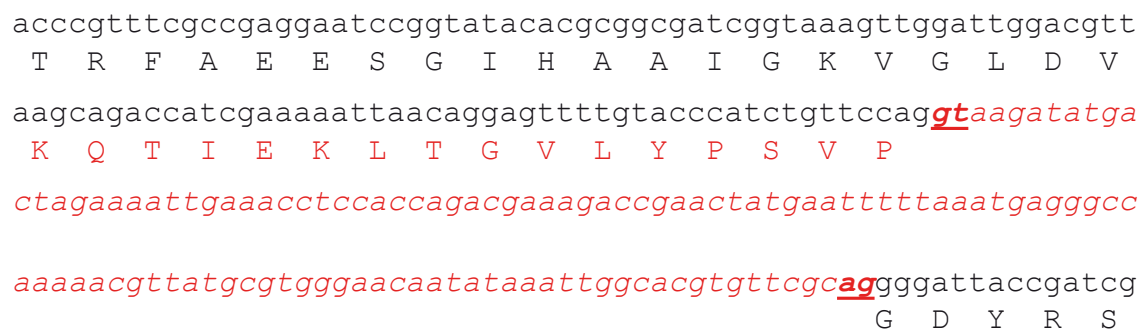

Figure 1: Apis densovirus possess a typical scindoambidensoviral intron in the VP1 gene. The VP1 intron is 117 bp long (italic). Splicing recognition sites are bold and underlined.

identical. Apis NS2 protein has best match in the S. invicta NS2 protein; they are $37 \%$ identical. Apis NS3 protein is however unique and has no orthologs. Apis VP protein is more divergent and shows only $31 \%$ amino acid identity with the Planococcus citri VP1 protein. We checked the conserved protein domains in the encoded Apis densovirus proteins and all of them are typical for densoviruses. In Apis VP protein, we can see the Parvo_coat_N domain (N-terminal region of the parvovirus VP1 coat proteins) and the large Denso_VP4 domain (capsid protein VP4 four different translation initiation sites of the densovirus capsid protein mRNA give rise to four viral proteins, VP1 to VP4). Parvo_coat_N domain indeed encodes a special parvoviral phospholipase $\mathrm{A}_{2}\left(\mathrm{PLA}_{2}\right)$ that is necessary for their infectivity (Zadori et al., 2001). It is conserved in Apis VP protein and encodes at least 34 amino acids, with the conserved active site of the PLA 2 and $\mathrm{Ca}^{2+}$-binding loop. In the NS1 protein, the DNA helicase protein that is required for the initiation of viral DNA replication is encoded in a protein domain named Parvo_NS1 superfamily. No conserved protein domains could be found in the NS2 and NS3 proteins.
In some of the Apis densovirus VP transcripts, we found an intron that is $117 \mathrm{bp}$ long (Fig. 1). The presence of introns in a VP gene is typical for the Scindoambidensovirus genus. Members of the Scindoambidensovirus genus are characterized by a split VP-encoding ORF, which gives rise to the VP1 minor capsid protein via a spliced transcript as well as another major capsid protein (VP2) containing a unique $\mathrm{N}$-terminal region, which has not been observed in any other parvovirus to date. The name "Scindo" refers to this split VP gene (Penzes et al., 2020, Tijssen et al., 2016). The Apis VP1 protein is 275 amino acids long, while the VP2 is 506 amino acids long. The presence of the split VP-encoding ORF in Apis densovirus indicates that it is most likely the new representative of the Scindoambidensovirus genus.

\subsection{APIS DENSOVIRUS IS A MEMBER OF THE SCINDOAMBIDENSOVIRUS GENUS}

To infer the phylogenetic affinity of Apis densovirus and relationships among densoviruses, we used their

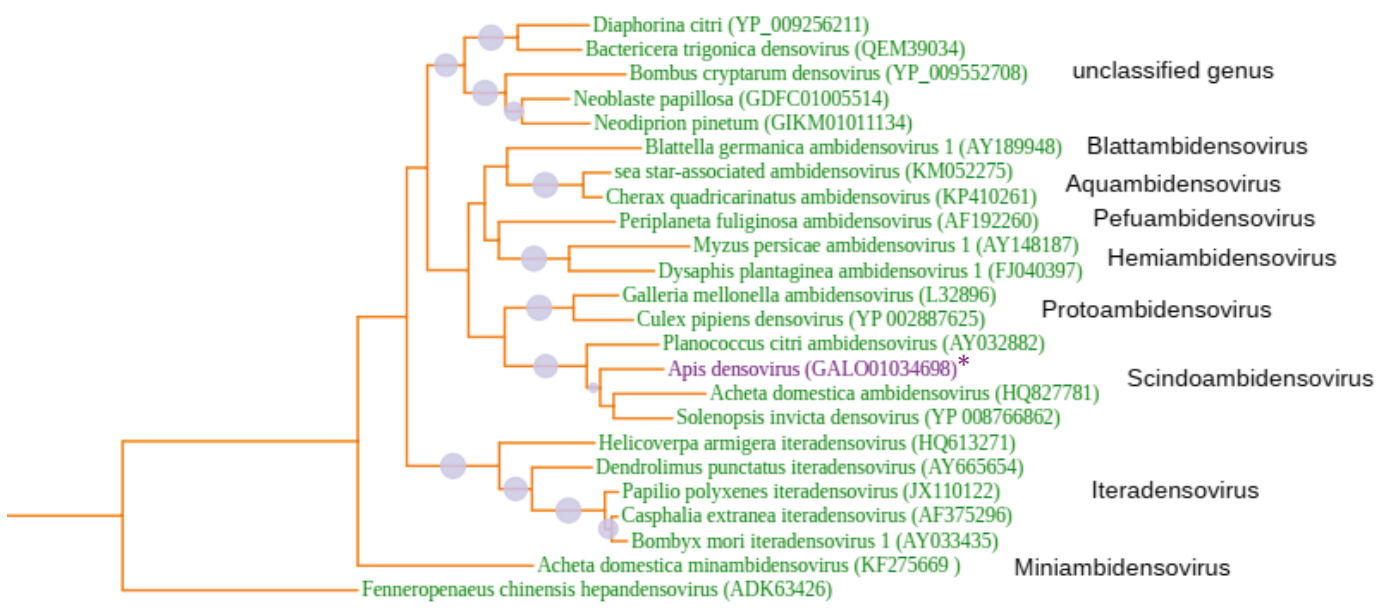

Figure 2: Maximum likelihood phylogeny of the densoviruses. The tree was inferred by IQTree program under a LG + F + I + G4 model from the NS1 proteins. Only bootstrap values larger than $80 \%$ are shown as circles. The hepandensovirus was used to root this tree. Apis densovirus is shown in cyan color with asterisk. 
NS1 protein sequences. Representatives of eight classified and one unclassified Densovirinae genera were included in the phylogenetic analysis. Best-fit model according to Bayesian information criterion was $L G+F+I+G 4$. Tree was rooted with the hepandensovirus. Maximum likelihood phylogenetic analysis confirmed that Apis ambidensovirus is a new member of the Scindoambidensovirus genus (Fig. 2). On the other side, the bumblebee (Bombus impatiens) densovirus is a representative of a novel unclassified Densovirinae genus.

\subsection{INFERRED GENOME ORGANISATION OF THE APIS AMBIDENSOVIRUS}

Ambidensoviruses share a genomic characteristic: all of them exhibit antisense genome organisation. They maintain the division of the genome into separate nonstructural (NS3 to NS1) and structural (VP capsid) gene cassettes; these cassettes are inverted with respect to one another. In ambisense densovirus genomes, the nonstructural proteins (NS3 to NS1) are expressed from an ORF in the left half of the genome. The capsid proteins are translated from an ORF on the right hand side of the genome, but from an RNA generated in the opposite orientation (Mietzsch et al., 2019). Although we lack direct evidence for the Apis densovirus genome, we can simply infer its genome sequence from the available NS and VP transcripts. While the obtained genome sequence is not complete, it contains nearly $90 \%$ sequence of the Apis densovirus. Missing are only terminal inverted repeats with promoters and the 50-100 bp in the center of the genome. The assembled partial Apis densovirus genome is currently 4786 bp long, while the expected complete genome size could be up to 5300 bp long (Fig. 3).

\subsection{APIS DENSOVIRUS IS NOT ENDOGENISED}

Previous studies of densoviruses in invertebrate genomes have found numerous endogenised densoviruses, some of them possessing complete genomes (Liu et al., 2011; Francois et al., 2016). We searched the available Apis genomes at the NCBI WGS and NCBI SRA databases for the presence of endogenised densoviruses. No endogenised densovirus sequences can be found in the available Apis genomes. The search for endogenised densoviruses in hymenopteran genomes showed that besides their presence in ant genomes they are also present in the bumblebee (Bombus impatiens) genome (AEQM02016195, 3848 bp long). This Bombus densovirus encodes intact NS1, NS2 and VP proteins (Fig. 4). It is most similar to the Bombus cryptarum and Diaphorina citri densoviruses but has very low level of similarity to the Apis densovirus (Fig. 2).

\subsection{POTENTIAL IMPACT OF THE APIS DENSOVI- RUS ON HONEY BEES}

The relationship between densoviruses and their arthropod hosts ranges from mutualism (Xu et al., 2014) to severe pathology (Szelei et al., 2011), which is especially problematic in large insect rearing facilities (Tijssen et al., 2016; Schoonvaere et al., 2018). Densoviruses are highly pathogenic for insects at larval stages, which are infected through the ingestion of contaminated food

tcgtcgtagaaactagttctaaaagtgatggacactctggccactctctctcgtaagtgcat

agcaagtaatatttctttcttaatatcgatactttatccggctatttgcccgatatatt aatacaggacataaagataactattggaaagattattgcgaatatctaacgtgcaaaga agaattaccccttcagtcgaaagagaagtacgaagacgagataaacatagtggtatcaac agagtattgtctacattcaacgcttgctataggtattaataagtggtgttgtaataattg cattcatacatttttaaaaatagacgaaaaggactgtttttatacacgtcagtaccgt acgatccgcttgtagagtttctagagcttataaagccatttgcggtaattgtgcaaagcc tgtacaattaaaagtatatgacgcaaaaggaattaaactagatcctattcatttttgttg gaacgacagttacacggttacgggaaacgtatatccaccagatggacgtcccaggatcag aaacgatactaccgttgaattcgttgagttatggaatcttatatgggatttgcttctga ctcaggagatcgaggaaactctgttggttcgacctcggatatgggaggaccttctggaga aaacattggaaaattactccagaaagaggattcaccggacatttcccagtacgaaaat taaagatttgtttccagaacagtttaagattttggaagataaattacaaaaagtggtcgg tcactacattcgaagaattgaggaacaagattttggaaaacaaaagatatattagcga cgttattcttcttcaaggacaagaacaccgtgatagatgcattcgacacctgcgccaaga atctggctcctacatgggtaaactcttcatatgggtcgttgaaacagatcacctgcacat cgtccacgattgcccctggtcaaacggatcttgtagatgcagaattcttgacgtaccctt cattcgacgacatgttcaaagagtgtgcgaagaaccaagtacatctcagaactcgacag

Fig. 3 continues on the next page 
aacagactacgaaggtatacttttatacttcattgtgtcgaaatgggaaagcgagcgaga aatttggattggaagaagatacagcgattacctgatcaagatgaaattgtacaatggca agatttgtcgcgaacagcatccgaattactggctagggaaactgaaggaggtggacatat cggtcccgagggatcatcctataatgacccacgtggaagcgatatttacgaagagtttga cggaacttcgaaaaaaggcgggcgattgacgacggaccacgacgggcaaaggaaaccaa atggaccaagattttatccaagatacaagccgtactgaccgagtttatgccaattccagc ggtgcacgttagagatctgctcgtaggcatacccgagtacgaatacttacacgatcccaa catcgataagtattatacgaacgcgtgttcatattatgtaaattctatttcaaatttcaa tttcatagatttctataatctatataacaatcgaacaccaatattttacgcgaataattt aatccatttagttattatcatacgcgggaagatagttttcaatatttgaatcgattgct aacgtatcaactaggaggagatacggatatcgttcgagaatttttgttcaatatgaaaga atggtttaatagaaagggatggaccggtaatcctaaattaatgcaatcgcggttatagg accacccaacagcggtaaaattattttttcgatgccgtagcgagcatagcttacaatgt cggacatatcggtagagttaataacaaaacgaataattttgcgttacaagaatgttattc caaagatttatagttggaaacgagattagtatggaggagggagcgaaagaagattttaa aaattatgcgaaggtaccgctttgaatatacgcgtaaagtatcagggagataaaatcta taagaagacaccagttctgttaatttcaaattctatgttagatatatgttccgatcctgc tttcaaaggtatcaggttagtaacgtttacgtggaacgttgcaccgtttttgagagactc tacgttgaaaccgtatccgttggcaatttttgatttatataatatgtatggNNNNNNNNN NNNNNNNNNNNNNNNNNNNNNNNNNNNNNNNNNNNNNNNNNNNNNNNNNNNNNNNNNNNN tttttttttttgaaataaaaaatttttattttttctttaaacttgatacaatcccgaaa atgttggaacggattcgtcggtagctgcacgcataacataaaagtcaccttctccggtta tacaattttctatgtgaggacgatatacaggatattgtgtattaatttccatttcggcta taacatcaaagtaaccttgagtatctgtaaaactattattactatcgtctaaaactaaag ttttagtacttaacgctaccgttggttgaacgcctacgtgcaaactcggttgggccettg gatgcgtatgaggatatatacccctccaaatttcttgacttctttcgatcttttgcgtca aaccgaagtatccgttttgatcggttttcaattccgagttagcgtaactatgcggttcgc tgttcacgttcatcgttatgatcttcgcttgaggagattgttccgaaggtccgtaattga cggtaactgtcgacgttttatccttattggcggcttgcggaatgccgtaccacttcggtg tgatcggtgttttacacagaccttccaacggttcgtattccacggagattaactctctgc tcatggcgtcttccgctagattttctacaactttttcttgtaaacattcccatcctacgt tcgtcttatcggtttgattttcgaacggagcgaataccattcctaaataaatgggaagta cttgcggtattccacattgatgtcgcggtacgcgagtgatatcgtaattcatgccgtaca tattatagtgaatattaagataatccgaatcgtcgactttatccatcgaggtaggtatca ttggttgattagcttgaaagatgtgtatttgataggcatagtggatagggaaagattca atccaactgcgtgaacggtagatttattttgatttaacgtggctaaattgttatccgtac tgttcgttgggaaagcaattctgacatttctcgttctaatctcgcatttaattttattta cggtggatccattcgggagaacattgaattcaccttgattgatatacaggaacattctat cccagggtatttcacacaaggagtagacagtatatatccaatacgactgttgtcagtat tattaagcttaaactgatagcgcgatacgccaatccgtaagtaagtatacgatgcacct tgcggtaatatctaatatgagaatgtatagataccaatggtgaaggtaatctttgaagac ttgaattatcgctagccacatcattgctgttaccctgttcctgtccagttccagttaact ttctttttttgcttttgggagcaccagatgaatcagatgcactatcagccgaagcttgt tgttttccgactggtggcatagaattatcgtcgatgttatccgtatgagcttcctcaaca accgaatcgtcctcgccttgtgattcttcaatttctggaataggatgatcgatcggtaat cccctgcgaacacgtgccaatttatattgttcccacgcataacgtttttggccctcattt aaaattcatagttcggtctttcgtctggtggaggtttcaattttctagtcatatcttac ctggaacagatgggtacaaactcctgttaatttttcgatggtctgcttaacgtccaatc caactttaccgatcgccgcgtgtataccggattcctcggcgaaacgggtcgcagcctctc gatccgcttccttcacctctgctacgaacgacgatttatcgatctgtcccttctcgtatt tctcttgaatttcctgatattttaaatcgtgatctctggctatttgatcgaccggattct tcgcagcttctatgggaatggaattgccaggtccgacgtagtcgcttccaggtaaagtat atccccttctatttgttattttttcggtaagatatcccccgataccgacagcagcggtac ctattgctgccgacgcaagtaacgtaggtgctgcaagagacgatcctgcaccgaccgcgg acgctgaactgaccgctccgacggatgccccgactccggatgcgaccgattccgatgctc cagctccctcggagggggaaatgcgaagtgaacctcttgtgccacctcgtctacgtaatc cgtctgcgttcggatttctctcgttcgtcgatccgatggattcccgttgacgtgatacat ttccttctccaacactgatatcggaggtggagttgtaaattccggagctagtgtagttgt

Fig. 3 continues on the next page 
agtctggttccccattaaatgcagtttcctctataccaaatgttcattatcaacctcgt tgtaatctaataatctgtgctcttcttcttgagttgttctgttttttagaaatttatcaa ttatacttctgtcccatccgaccgcttcgcttgccatgacacttatgatcttctctcata tttatctccttatataatatccatatcgttgttacgtaacactcgtaatctcgcaagctg agttcttgccgaatatcaacctccagttgatatttcccgacgacgacgcct

\section{NS3}

MDTLATLSRKCIASNISELNIDTLSGYLPDILIQDIKDNYWKDYCEYLTC KEELPLQSKEKYEDEINIVVSTEYCLHSTLAIGINKWCCNNCI HTFLKNR RKGTVFIHVSTVRSACRVSRAYKAICGNCAKPVQLKVYDAKGIKLDPIHF CWNDSYTVTGNVYPPDGRPRIRKRYYR*

\section{NS2}

MDVPGSENDTTVEFVELWNLIWDLLLTQEIEETLLVRPRIWEDLLEKTLE KLLQKEDSPDISQYEKLKICFQNSLREWKINYKKWSVTTFEELRNKILEK QKDILATLFFFKDKNTVIDAFDTCAKNLAPTWVNSSYGSLKQITCTSSTI APGQTDLVDAEFLTYPSFDDMFKRVCEEPSTSQNSTEQTTKVYFYTSLCR NGKASEKFGLEEEYSDYLIKMKLYNGKICREQHPNYWLGKLKEVDISVPR DHP IMTHVEA IFTKSLTELRKKGGRLTTDHDGQRKPNGPRFYPRYKPY*

\section{NS1}

MESYMGFASDSGDRGNSVGSTSDMGGPSGENIGKITPERGFTGHFPVRKI KDLFPEQFKI LEDKLQKVVGHY IRRIEEQDFGKTKRY I SDVILLQGQEHR DRC IRHLRQESGSYMGKLF IWVVETDHLH IVHDCPWSNGSCRCRI LDVPF IRRHVQKSVRRTKY I SELDRTDYEGI LLYF IVSKWESEREIWI GRRIQRL PDQDE IVQWQDLSRTASELLARETEGGGHIGPEGSSYNDPRGSDIYEEFD GTSKKRRAIDDGPRRAKETKWTKILSKIQAVLTEFMPI PAVHVRDLLVGI PEYEYLHDPNIDKYYTNACSYYVNS I SNFNF IDFYNLYNNRTP IFYANNL NPESYYHTREDSFQYLNRLLTYQLGGDTDIVREFLFNMKEWENRKGWTGN PKINAIAVIGPPNSGKNYFFDAVAS IAYNVGHIGRVNNKTNNFALQECYS KRFIVGNEISMEEGAKEDFKKLCEGTALNIRVKYQGDKIYKKTPVLLISN SMLDICSDPAFKGIRLVTFTWNVAPFLRDSTLKPYPLAIFDLYNMYG

\section{VP1}

MASEAVGWDRS I I KFLKNRTTQEEEHRLLDYNEVDNEHFGIEETAFNGE PDYNYTSSGIYNSTSDISVGEGNVSRQRES IGSTNERNPNADGLRRRGGT RGSLRISPSEGAGASESVASGVGASVGAVSSASAVGAGSSLAAPTLLASA AIGTAAVGIGGYLTEKITNRRGYTLPGSDYVGPGNS IPIEAAKNPVDQIA RDHDLKYQEIQEKYEKGQIDKSSFVAEVKEADREAATRFAEESGIHAAIG KVGLDVKQTIEKLTGVLYPSVPGKI *

\section{VP2}

MRAKNVMRGNNINWHVFAGDYRS I I LFQKLKNHKART IRLLRKLIRITST I I LCHQSENNKLRL IVHLIHLVLPKAKKRKLTGTGQEQGNSNDVASDNSS LQRLP S PLVS I HSH IRYYRKVHR ILTYGLAYRA ISFKLNNTDNSRIGYIL STPLCEI PWDRMFLY INQGEFNVLPNGSTVNKIKCEIRTRNVRIAFPTNS TDNNLATLNQNKSTVHAVGLNLSLSTMPIKYTSFQANQPMI PTSMDKVDD SDYLN I HYNMYGMNYDITRVPRHQCGI PQVLPIYLGMVFAPFENQTDKTN VGWECLQEKVVENLAEDAMSRELISVEYEPLEGLCKTP ITPKWYGI PQAA NKDKTSTVTVNYGPSEQSPQAKI ITMNVNSEPHSYANSELKTDQNGYFGL TQKIERSQEIWRGIYPHTHPRAQPS LHVGVQPTVALSTKTLVLDDSNNSF TDTQGYFDVIAEMEINTQYPVYRPHIENCITGEGDFYVMRAATDESVPTF SGLYQV*

Figure 3: The nucleotide sequence of the Apis ambidensovirus genome with encoded NS and VP proteins. Partial Apis densovirus genome was reconstructed from the two transcripts (GALO01034698 and GALO01020879). This genome is 4786 bp long, the gap in the middle of the genome is from 6 to $60 \mathrm{bp}$ long (or 2 to 20 amino acids long); missing are ITRs. 
ATAAACACGATACTAGAATATCTCAGACATACCTCAATGGGTGATATCGGCGAATTGTTTTGTCGCGAGG ATATACCAGAAGAGTTCGAGACATTTGTGGATCAAGTAATAGCTGGTGAGTGCGAAAATGAATCAAATTT TGGATATATTGCCGAAAACCGATCTAACATTGGAGAAGCTTCATGTTCTGGAAATGTGCCTATGGAGATT AGCGAAAGAGTATATGGATTCTCAGAACAAGGATCAGCTGCTTATATGGTTCCACCGGGTGAAAGCATTA CAGCAACACAGAGAGATGCTGCTGAAAGACGAAAATTGCTCAGGCAAATATTCTTGGAAAGATTTGAGAG CCAGCATAGACGCAACTCAGTCTGCCATCAAATTTTTAGTAAAAGAAGTATCCCAGGAGCTAATGCTGAA ATTAAAAGAGTGGTACAAGGAAATTTCGAGGAACAGCTTATTTGGTATGCGATCACGGAGACCACTATC ACATTGTGCACGACTGCCATAGATCAGGGCAAAGATGTCGCTGTCATCGACTCGACGAAACCAGGAACGT CTTCGGTCGAGCAGTGTCTGAACGAGTTGTTAGAGACAACATCTTCGACATCGAACATTGGATCAATCTC GCAGAGTATTTCCAAAAAGACGAACGGCACCTTATCTACATGGAAGTCTGCGGGAGAGAAAGGACTGAAT GTGTTCAAAATAGAAAAGTATTCGTTCAAGGAAGTGTCCAAGCTAGACAAGACGAAATGGTGGATGACAC CGTCAGCAGTGAGAGCCCTATTCGTGACTTCCTCTCCTTTGGATCCTGTGGCGATACATGCAGACCAAGT ACTGCTGCTGGGGACGAAGAGGTTGACCAAGCTGCCCGGAGTTCAGAAGGAGGAAAAACAACTAATGTCG AAAAATACATACGAAAGTTTCTCACGTCTCCAATAACACATTTACTATCTACATCATATTGGATTAATTC GAAGTACTATATGATCAATACACAATCTAATTGGTTTCAATGTGTTATGCGTAAGATATCTTTTTCATTT AATCGTATGACTATATACGAATTATTTCAATACGCTAAACCACTGGATATGGATAAGCTGCTATATAGTA GTCCTACGGAAATGATATTCGATTATTACTATGATATACGCACAAGTGTATACATTTTGGATGAGCTACT ACGATTCCAGATGCAAGATGAAGATGAAATTGTATCATTCTTGGAAGTTCTATTAGCTGTCTTGGATAAA TCAATACCGAAGAAGAATTGCTTACATATACAAGGACCACCATGTTCAGGGAAGAACCTATTCTTCGACT GTGTGACATCGTTTTGTATTAATTGCGGACACTTGGGCAATTTCAACAAGTATAATTCTTTTCCGATGAT GGATTGTATAGATAAACGTGTTATCATGTGGAATGAGCCTATCTTAGAAGTATCAGCACTCGAAACATTA AAAATGGTATTCGGTGGAGATACTTGTCCTGTTAAAGTTAAATATCTCGGAGATAAGTTATTGCTTCGTA CTCCGATTATCTGTTTATCGAATAATCAGCCATTTCCACAGGATGACGCATTTACCTGTCGTATGTTTAC TTACCAATGGCAACAATGTAATGATTTAAAGAAAGTATCAAAAAAACCTCATCCTTTAGCTTTTCCTTAC CTATTAATAAAATATAAGATATGGGAAGATGTAGAATTGAATGAGAAAGAAAAAGAATATTTATATTAAT AAACATTTATTCAGCATAATATATGTGTACATTTAATTTACAGTATCCTGACCCATATTACTTAGTCTAT CAAATTTATTTCCTAAATTACGACGAACAGGTCCCATCCTCTCATCATCCCTATATGCCATCTTATATTG AGCTGCTCTTGGTGGATTTGGTGGAGTGAAGTCCTCTGTTTGTGTTGATCTTGTAGCAGGTGGTTCAGGT GCTGGCATAGCAACCAATCCAGATAGTTGACAATATCCATTGTATGCTCTATTTCCAACCCATATAGTAG TATCTGATGGAAATTGTACTGTGCCATTCTCCGAATAGTATGATCCATGATGTAGTTCAACATCTAATTC AGCTTCAACTGCCCAATATGCAGATGTATTCTGGAATGTAGTACTATCCGATCCTGGAGTCATAGCTGGT ACTGCCTGAATTCCTATATGTATTTGTGGTTGTGCTTTAAATGGGAATCCTCCATTCTGGAAATTATGTC CACСTTTCTCCAAAAATTGTTCTACATTTGTTACGGGAGTAGAATTGTAATCATTTATTTTATCGCTTAT ATCTGTAGTATGTGCTGCACCTAATGTTGTACTATGATCTCCATTCTTTATTACTTCTAATGCAAATGCT CTAGTACGTGGACCACCATAATGTACATATCTTGTATGAACATTAGGAGGATTATAATAGGGTGCACTAA TAGGAGCATGTTTACACTTATACGTATAATTAACTACAGGTTTTCCTATTGCTGTGTTTATTAGAAATTG ATCTACAAATTGATCTTTACGCATCTGTCCGTGATTGTTAGTGAACACTGTTGCACCAGTCGTAGGTCCT GGACTAACAAATGCTGCATATCCCACTGTATGTCTTGTGACTAGATTAGTATGTGAATCATCCGCTCTAT AGTATTTGTTAATTATATCGCTAGCATTAATCAATGACATATTATTCGGTTTCATATTATCCATTGTTCC ATATGTACAATTTACAATTCTGTATTTACATTCAGTCCTACAGATACTAATCCTATAGGTACAAATTCG TTAGTAGTATGTCCTGATGTTGTCCCTCCAAATTCAAACGCAGTACGAATACCGAGAGGTGTTACTTTAA CACGACATTCTTTAGCCCATGCATTATTTGGTAATTCTCTAAATTCGGTAGGTGATAAATAAAATCCAAC TAAATCTGTAGGTATTAAAGCTAATGGTGTTGTATAATAATCATCGCTGTTATTATTTATTCTCTTTGTA CATATTCCATAGCTGAAGAATATTCTATTCTTACGGAATGTAACAATAGATGGTTTAGGTGCAAGAGGTC TAGGTATAGTAACAATGTGTCCTACAGTGTGACTACCACTACTACGTCCACTAGCACCTGATGGACCAGA TGCTGCTAACACCTGATTATCATTCACACCATTTATACTTGGTACATCGAACTCCATGCCTTCTATATCG TTAAACAATCCCAATAGACTATTATCTGATCCCTGACTACTGTCTGGTTGTTGTATTTGTTCTTCTTGTT GTTCCTGTGGTACGTATTTACTTGTTCCTGGCTGATTTCTCTTTAATTCGTCCCAGGCGTCCTTTGAATG GGCTTGTTGTATCTCTCGAAAGGATAATCCTGTCTCTCTACTAGTATCTGCTAATTGTCTCTGTATTTGT GCGTACCTCTTTCTTTGTTCCAACTGTGCTGGTGTTGGTTGTCTTCTCTTCATATTAGGATATAACACTC CTGTCAAGGATTCTACACCATACTTAGCTGCTAATCCTGCAGCACCCAAATAACCATGTGGTGATTGTAA TTCCCAAAAATGTTTATGGCGTCTCGATCTGCCTCTCTTATATCTTCCTCAGTCTTTGCACGATCATAC AAATTATCATGTATTCTCGCTATTTCATCGTCTTCATCCACTGGTTCACCGTTCTTCAATTTATTCCCTG GCCCTAAATAGCGATGGCCGTACCAATTCATACTGACTTATATCATCTCATCGCATGTCTTATATAGTCT GAATAGATCGTATGGTAGGGTGCTCCGAGAATCACAGGTAAACTATTATGATCTATTCCATCCTTACT

Fig 4 continues on the next page 
NS1 (70\% aa id with Bombus cryptarum densovirus) INTILEYLRHTSMGDIGELFCREDI PEEFETFVDQVIAGECENESNFGYI AENRSNIGEASCSGNVPMEISERVYGFSEQGSAAYMVPPGES ITATQRDA AERRKLLRQIFLERFESQHRRNSVCHQIFSKRS I P GANAEIKRVVQGNFR GTAYLVCDHGDHYHIVHDCHRSGQRCRCHRLDETRNVFGRAVSERVVRDN IFDIEHWINLAEYFQKDERHLIYMEVCGRERTECVQNRKVFVQGSVQARQ DEMVDDTVSSESP IRDFLSFGSCGDTCRPSTAAGDEEVDQAARSSEGGKT TNVEKYIRKFLTSPITHLLSTSYWINSKYYMINTQSNWFQCVMRKISFSF NRMTIYELFQYAKPLDMDKLLYSSPTEMIFDYYYDIRTSVYILDELLRFQ MQDEDEIVSFLEVLLAVLDKS I PKKNCLHIQGP PCSGKNLFFDCVTSFCI NCGHLGNFNKYNS F PMMDC I DKRVIMWNE P I LEVSALETLKMVFGGDTCP VKVKYLGDKLLLRTP I ICLSNNQPFPQDDAFTCRMFTYQWQQCNDLKKVS KKPHPLAFPYLLIKYKIWEDVELNEKEKEYLY*

NS2 (76\% aa id with Bombus cryptarum densovirus) MNQ ILD I LPKTDLTLEKLHVLEMCLWRLAKEYMDS QNKDQLLIWEHRVKA LQQHREMLLKDENCSGKYSWKDLRAS I DATQSA I KFLVKEVSQELMLKLK EWYKEIFEEQLIWYAITETTITLCTTAIDQGKDVAVIDSTKPGTSSVEQC LNELLETTSSTSNIGSISQS ISKKTNGTLSTWKSAGEKGLNVFKIEKYSF KEVSKLDKTKWWMTPSAVRALFVTS SPLDPVAIHADQVLLLGTKRLTKLP GVQKEEKQLMSKNTYESFSRLQ*

VP1 (59\% aa id with Bombus cryptarum densovirus) MNWYGHRYLGPGNKLKNGEPVDEDDEIARI HDNLYDRAKTEEDIREADRD AIKHFWELQS PHGYLGAAGLAAKYGVESLTGVLYPNMKRRQPTPAQLEQR KRYAQIQRQLADTSRETGLSFREIQQAHSKDAWDELKRNQPGTSKYVPQE QQEEQIQQPDSSQGSDNSLLGLFNDIEGMEFDVPS INGVNDNQVLAASGP SGASGRSSGSHTVGH IVTI PRPLAPKPSIVTFRKNRIFFSYGICTKRINN NSDDYYTTPLALIPTDLVGFYLSPTEFRELPNNAWAKECRVKVTPLGIRT AFEFGGTTSGHTTNE FVPIGLVSVGLNVNTE IVNCTYGTMDNMKPNNMSL INASD I INKYYRADDSHTNLVTRHTVGYAAFVSPGPTTGATVFTNNHGQM RKDQFVDQFLINTAI GKPVVNYTYKCKHAPISAPYYNP PNVHTRYVHYGG PRTRAFALEVIKNGDHSTTLGAAHTTDISDKINDYNSTPVTNVEQFLEKG GHNFQNGGFPFKAQPQIHIGIQAVPAMTPGSDSTTFQNTSAYWAVEAELD VELHHGSYYSENGTVQFPSDTTIWVGNRAYNGYCQLSGLVAMPAPEPPAT RSTQTEDFTP PNP PRAAQYKMAYRDDERMGPVRRNLGNKFDRLSNMGQDT $\mathrm{VN} *$

Figure 4: The nucleotide sequence of the endogenised Bombus impatiens densovirus genome with encoded NS and VP proteins. Partial ambisense Bombus impatiens densovirus genome was obtained from the NCBI WGS database (AEQM02016195). This genome is 3848 bp long, missing are ITRs.

(Tijssen et al., 2016). In honey bees, brood diseases are common and are caused by fungi, bacteria and viruses (Brutscher et al., 2016). Until now, among the honey beeinfecting viruses, only the Sacbrood virus was connected with the honey bee brood disease (Brutscher et al., 2016). The question to be resolved is whether densoviruses infecting pollinators (honey bees and bumblebees) exert any detectable pathological effects on them.

\subsection{INFORMATION ABOUT THE ORIGIN OF THE EASTERN HONEY BEE TRANSCRIPTOME}

The honey bee transcriptome in which we found the first Apis densovirus was erroneously classified as Apis mellifera carnica transcriptome (SRR922440, 52.177 con- tigs) and is still available under such name. It was produced from the whole heads of the workers by the researchers from the Yangzhou University, Jiangsan Province, China (Ji et al., 2014). The analysis of the SRR 922440 transcriptome showed that $86 \%$ of contigs have strong signals to the Apis cerana and only $1.2 \%$ to the Apis mellifera. China, the largest producer of honey, introduced $A$. mellifera (diverse subspecies, including carnica) besides the native A. cerana. Since the erroneous classification of transcriptomes is misleading, we also investigated the origin of the SRR922440 transcriptome with complete mitochondrial genomes of A. cerana and A. mellifera carnica. This analysis demonstrated that the SRR922440 transcriptome originates from the Apis cerana, since numerous sequences show $99 \%$ identity with the mitochondrial genome of $A$. cerana. The authors of this transcriptome (Ji et al., 2014) 
provided some information about the origin of the $A$. cerana colonies: $\mathrm{M}$ and $\mathrm{C}$ colonies were unrelated local strains in the same A. cerana population and were bred in the Guandong Entomological Institute, Guangzhou (also known in the West as the Canton), southern China. All Apis densovirus transcripts were obtained from the $\mathrm{C}$ colony that was Varroa resistant. No information about the health status of the bees was provided in the original reference (Ji et al., 2014). We checked if these bees were infected with some RNA viruses, discovering only a fulllength Sacbrood virus in this transcriptome (in the sequence GALO01042235). It should be noted that the additional A. cerana brain transcriptome is available at the NCBI TSA database (SRR361851), but shows the absence of the Apis densovirus. This transcriptome was produced by the researchers from the Fujian University: eastern honey bees originated from the Honey bee Research Institute, Jiangxi Agricultural University, Nanchang, Jiangxi province, east China. The availability of diverse A. cerana transcriptomes therefore shows limited presence of Apis densovirus in southern China.

\section{CONCLUSIONS}

Viruses, especially RNA viruses, pose a major threat to the survival of honey bees. Combined with additional stressors, the consequences for honey bees and agriculture can be extremely severe. Here, we present the first densovirus in honey bees, which can pose a potential threat to them. Densoviruses are often associated with high mortality and great economic losses in commercially important infected insects, such as farmed crickets and silk moths. Given that densoviruses have also been detected in bumblebees, their potential pathogenicity could pose a serious threat to diverse pollinators (honey bees and bumblebees) and consequently to agriculture. The availability of the nucleotide sequence for the honey bee and and bumblebee ambidensovirus genomes, its transcripts, and all coding proteins provides a good starting point for more detailed studies of the pathogenicity of densoviruses in honey bees and bumblebees. Research on the effects of infection on the survival of honey bee colonies is also needed, as larvae are the most common victims of densoviruses in the majority of infected insects. We detected the densovirus only in eastern honey bees (Apis cerana) from southern China. Of course, this does not mean that this virus is not more widespread or that it lacks the potential to rapidly spread around the world. Dead larvae should be tested for the presence of the Apis densovirus. Research on densoviruses in diverse pollinators and their impact on the survival of honey bees and bumblebees is therefore urgently needed.

\section{ACKNOWLEDGEMENTS}

The authors thank Prof. Roger H. Pain for his critical reading of the manuscript. This work was supported by the Slovenian Research Agency grant P1-0207.

\section{REFERENCES}

Bailey, L., Ball, B. V., Woods, R. D. (1976). An iridovirus from bees. Journal of General Virology, 31, 459-461. https://doi.org/10.1099/0022-1317-31-3-459

Beaurepaire, A., Piot, N., Doublet, V., Antunez, K., Campbell, E., Chantawannakul, P., ... Chejanovsky, N. (2020). Diversity and global distribution of viruses of the western honey bee, Apis mellifera. Insects, 11, 239. https://doi.org/10.3390/insects11040239

Bromenshenk, J. J., Henderson, C. B., Wick, C. H., Stanford, M. F., Zulich, A. W., Jabbour, R. E., ... Deshpande, S. V., (2010). Iridovirus and Microsporidian Linked to Honey Bee Colony Decline. PLoS ONE, 5, e13181. https://doi.org/10.1371/journal.pone.0013181

Brutscher, L. M., McMenamin, A. J., Flenniken, M. L. (2016). The buzz about honey bee viruses. PLoS Pathogens, 12, e1005757. https://doi.org/10.1371/journal.ppat.1005757

Chen, Y. P., Siede, R. (2007). Honey bee viruses. Advances in Virus Research, 70, 33-80. https://doi.org/10.1016/S00653527(07)70002-7

Cotmore, S. F., Agbandje-McKenna, M., Chiorini, J. A., Mukha, D. V., Pintel, D. J., Qiu, J., ... Soderlund-Venermo, M., (2014). The family Parvoviridae. Archives of Virology, 159, 1239-1247. https://doi.org/10.1007/s00705-013-1914-1

Evans, J. D., Schwarz, R. S. (2011). Bees brought to their knees: microbes affecting honey bee health. Trends in Microbiology, 19, 614-620. https://doi.org/10.1016/j.tim.2011.09.003

Francois, S., Filloux, D., Roumagnac, P., Bigot, D., Gayral, P., Martin, D. P., ... Froissart, R. (2016). Discovery of parvovirusrelated sequences in an unexpected broad range of animals. Scientific Reports, 6, 30880. https://doi.org/10.1038/srep30880

Fürst, M. A., McMahon, D. P., Osborne, J. L., Paxton, R. J., Brown, M. J. (2014). Disease associations between honeybees and bumblebees as a threat to wild pollinators. Nature, 506, 364-366. https://doi.org/10.1038/nature12977

Galbraith, D. A., Fuller, Z. L., Ray, A. M., Brockmann, A., Frazier, M., Gikungu, M. W., ... Martinez, J. F. I. (2018). Investigating the viral ecology of global bee communities with high-throughput metagenomics. Scientific Reports, 8, 8879. https://doi.org/10.1038/s41598-018-27164-z

Gauthier, L., Cornman, S., Hartmann, U., Cousserans, F., Evans, J. D., de Miranda, J. R., Neumann, P. (2015). The Apis mellifera filamentous virus genome. Viruses, 7, 3798-3815. https://doi.org/10.3390/v7072798

Gertz, E. M., Yu, Y. K., Agarwala, R., Schäffer, A. A., Altschul, S. F. (2006). Composition-based statistics and translated nucleotide searches: improving the TBLASTN module of BLAST. BMC Biology, 4, 41. https://doi.org/10.1186/1741-7007-4-41

Goulson, D., Nicholls, E., Botias, C., Rotheray, E. L. (2015). Bee declines driven by combined stress from parasites, 
pesticides, and lack of flowers. Science, 347, 1255957. https://doi.org/10.1126/science.1255957

Grozinger, C. M., Flenniken, M. L. (2019). Bee viruses: ecology, pathogenicity, and impacts. Annual Review of Entomology, 64, 205-226. https://doi.org/10.1146/annurev-ento-011118-111942

Hartmann, U., Forsgren, E., Charriere, J. D., Neumann, P., Gauthier, L. (2015). Dynamics of Apis mellifera filamentous virus $(\mathrm{AmFV})$ infections in honey bees and relationships with other parasites. Viruses, 7, 2654-2667. https://doi.org/10.3390/ v7052654

Ji, T., Yin, L., Liu, Z., Shen, F., Shen, J. (2014). High-throughput sequencing identification of genes involved with Varroa destructor resistance in the eastern honeybee, Apis cerana. Genetics and Molecular Research, 13, 9086-9096. https://doi.org/10.4238/2014.October.31.24

Katoh, K., Standley, D. M. (2013). MAFFT multiple sequence alignment software version 7: improvements in performance and usability. Molecular Biology and Evolution, 30, 772-780. https://doi.org/10.1093/molbev/mst010

Klein, A. M., Vaissiere, B. E., Cane, J. H., Steffan-Dewenter, I., Cunningham, S. A., Kremen, C., Tscharntke, T. (2007). Importance of pollinators in changing landscapes for world crops. Proceedings of the Royal Society B, 274, 303-313. https://doi.org/10.1098/rspb.2006.3721

Kraberger, S., Cook, C. N., Schmidlin, K., Fontenele, R. S., Bautista, J., Smith, B., Varsani, A. (2019). Diverse single-stranded DNA viruses associated with honey bees (Apis mellifera). Infection, Genetics and Evolution, 71, 179-188. https://doi.org/10.1016/j. meegid.2019.03.024

Letunic, I., Bork, P. (2019). Interactive Tree Of Life (iTOL) v4: recent updates and new developments. Nucleic Acids Research, 47(W1), W256-W259. https://doi.org/10.1093/nar/gkz239

Levitt, A. L., Singh, R., Cox-Foster, D. L., Rajotte, E., Hoover, K., Ostiguy, N., Holmes, E. C. (2013). Cross-species transmission of honey bee viruses in associated arthropods. Virus Research, 176, 232-240. https://doi.org/10.1016/j.virusres.2013.06.013

Liu, H., Fu, Y., Xie, J., Cheng, J., Ghabrial, S. A., Li, G., ... Peng, Y., (2011). Widespread endogenization of densoviruses and parvoviruses in animal and human genomes. Journal of Virology, 85, 9863-9876. https://doi.org/10.1128/JVI.00828-11

Martin, S. J., Highfield, A. C., Brettell, L., Villalobos, E. M., Budge, G. E., Powell, M., ... Nikaido, S. (2012). Global honey bee viral landscape altered by a parasitic mite. Science, 336, 1304-1306. https://doi.org/10.1126/science.1220941

McMenamin, A. J., Flenniken, M. L. (2018). Recently identified bee viruses and their impact on bee pollinators. Current Opinion in Insect Science, 26, 120-129. https://doi.org/10.1016/j. cois.2018.02.009

McMenamin, A. J., Brutscher, L. M., Glenny, W., Flenniken, M. L. (2016). Abiotic and biotic factors affecting the replication and pathogenicity of bee viruses. Current Opinion in Insect Science, 16, 14-21. https://doi.org/10.1016/j.cois.2016.04.009

McMenamin, A. J., Genersch, E. (2015). Honey bee colony losses and associated viruses. Current Opinion in Insect Science, 8, 121-129. https://doi.org/10.1016/j.cois.2015.01.015

Mietzsch, M., Penzes, J. J., Agbandje-McKenna, M. (2019). Twenty-five years of structural parvovirology. Viruses, 11, 362. https://doi.org/10.3390/v11040362
Penzes, J. J., Söderlund-Venermo, M., Canuti, M., Eis-Hübinger, A. M., Hughes, J., Cotmore, S. F., Harrach, B. (2020). Reorganizing the family Parvoviridae: a revised taxonomy independent of the canonical approach based on host association. Archives of Virology, 165, 2133-2146. https://doi.org/10.1007/s00705020-04632-4

Potts, S. G., Biesmeijer, J. C., Kremen, C., Neumann, P., Schweiger, O., Kunin, W. E. (2010). Global pollinator declines: trends, impacts and drivers. Trends in Ecology and Evolution, 25, 345-353. https://doi.org/10.1016/j.tree.2010.01.007

Remnant, E. J., Shi, M., Buchmann, G., Blacquiere, T., Holmes, E. C., Beekman, M., Ashe, A. (2017). A diverse range of novel RNA viruses in geographically distinct honey bee populations. Journal of Virology, 91, e00158-17. https://doi.org/10.1128/ JVI.00158-17

Schoonvaere, K., Smagghe, G., Francis, F., de Graaf, D. C. (2018). Study of the Metatranscriptome of Eight Social and Solitary Wild Bee Species Reveals Novel Viruses and Bee Parasites. Frontiers in Microbiology, 9, 177. https://doi.org/10.3389/ fmicb.2018.00177

Shi, M., Lin, X. D., Tian, J. H., Chen, L. J., Chen, X., Li, C. X., ... Qin, X. C. (2016). Redefining the invertebrate RNA virosphere. $\mathrm{Na}$ ture, 540, 539-543. https://doi.org/10.1038/nature20167

Steffan-Dewenter, I., Potts, S. G., Packer, L. (2005). Pollinator diversity and crop pollination services are at risk. Trends in Ecology and Evolution, 20, 651-652. https://doi.org/10.1016/j. tree.2005.09.004

Szelei, J., Woodring, J., Goettel, M. S., Duke, G., Jousset, F. X., Liu, K. Y., ... Zadori, Z. (2011). Susceptibility of North-American and European crickets to Acheta domesticus densovirus (AdDNV) and associated epizootics. Journal of Invertebrate Pathology, 106, 394-399. https://doi.org/10.1016/j.jip.2010.12.009

Tijssen, P., Penzes, J. J., Yu, Q., Pham, H. T., Bergoin, M. (2016). Diversity of small, single-stranded DNA viruses of invertebrates and their chaotic evolutionary past. Journal of Invertebrate Patholology, 140, 83-96. https://doi.org/10.1016/j. jip.2016.09.005

Tokarz, R., Firth, C., Street, C., Cox-Foster, D. L., Lipkin, W. I. (2011). Lack of Evidence for an Association between Iridovirus and Colony Collapse Disorder. PLoS ONE, 6, e21844. https://doi.org/10.1371/journal.pone.0021844

Trifinopoulos, J., Nguyen, L. T., Von Haeseler, A., Minh, B. Q. (2016). W-IQ-TREE: a fast online phylogenetic tool for maximum likelihood analysis. Nucleic Acids Research, 44(W1), W232-W235. https://doi.org/10.1093/nar/gkw256

Valles, S. M., Shoemaker, D. W., Wurm, Y., Strong, C. A., Varone, L., Becnel, J. J., Shirk, P. D. (2013). Discovery and molecular characterization of an ambisense densovirus from South American populations of Solenopsis invicta. Biological Control, 67, 431-439. https://doi.org/10.1016/j.biocontrol.2013.09.015

Xu, P., Liu, Y., Graham, R. I., Wilson, K., Wu, K. (2014). Densovirus is a mutualistic symbiont of a global crop pest (Helicoverpa armigera) and protects against a baculovirus and Bt biopesticide. PLOS Pathogens, 10, e1004490. https://doi.org/10.1371/ journal.ppat. 1004490

Zadori, Z., Szelei, J., Lacoste, M. C., Li, Y., Gariepy, S., Raymond, P., ... Allaire, M. (2001). A viral phospholipase $A_{2}$ is required for parvovirus infectivity. Developmental Cell, 1, 291-302. https:// doi.org/10.1016/S1534-5807(01)00031-4 